OPEN ACCESS

Edited by:

Andrew R. Gennery,

Newcastle University, United Kingdom

Reviewed by:

Kohsuke Imai,

Tokyo Medical and Dental

University, Japan

Antonio Condino-Neto,

University of São Paulo, Brazil

*Correspondence:

Benedicte Neven

benedicte.neven@aphp.fr

†These authors have contributed equally to this work

Specialty section:

This article was submitted to

Pediatric Immunology,

a section of the journal

Frontiers in Pediatrics

Received: 11 July 2019 Accepted: 17 December 2019 Published: 24 January 2020

Citation:

Neven B and Ferrua F (2020)

Hematopoietic Stem Cell

Transplantation for Combined Immunodeficiencies, on Behalf of IEWP-EBMT. Front. Pediatr. 7:552.

doi: 10.3389/fped.2019.00552

\section{Hematopoietic Stem Cell Transplantation for Combined Immunodeficiencies, on Behalf of IEWP-EBMT}

\author{
Benedicte Neven ${ }^{1,2,3 * t}$ and Francesca Ferrua ${ }^{4 t}$ \\ ${ }^{1}$ Université de Paris, Paris, France, ${ }^{2}$ Pediatric Hematology-Immunology and Rheumatology Unit, Necker-Enfants Malades \\ Hospital, Assistance Publique-Hôpitaux de Paris (APHP), Paris, France, ${ }^{3}$ INSERM U1163 and Imagine Institute, Paris, \\ France, ${ }^{4}$ San Raffaele Telethon Institute for Gene Therapy (SR-Tiget), Pediatric Immunohematology and Bone Marrow \\ Transplantation Unit, San Raffaele Scientific Institute, Milan, Italy
}

Combined immunodeficiencies (CIDs) are a clinically and genetically heterogeneous group of primary immunodeficiencies (PIDs) that affect T-lymphocyte immunity with abnormal development or function. As compared to severe combined immune deficiencies (SCID), these patients are usually diagnosed later. They display a broad infectious susceptibility; immune dysregulation manifestations and chronic lymphoproliferation are also frequent. These complications and their specific treatments can lead to persistent damage to several organs. Prognosis of CIDs is worse as compared to other PIDs. The curative treatment is usually hematopoietic stem cell transplantation (HSCT), but difficult questions remain regarding the definitive indication of HSCT and its timing; the final decision depends on a conjunction of factors such as immunological parameters, severity of clinical manifestations, and natural history of the disease, when molecular diagnosis is known. CD40L deficiency, a CID caused by mutations in CD4OLG gene, well illustrates the dilemma between HSCT vs. long-term supportive treatment. This disease leads to higher risk of developing infections from bacterial and intracellular pathogens, especially Pneumocystis and Cryptosporidium spp. While supportive care allows improved survival during childhood, organ damages may develop with increasing age, mainly chronic lung disease and biliary tract disease (secondary to Cryptosporidium spp. infection) that may evolve later to sclerosing cholangitis, a severe complication associated with increased mortality. Early HSCT before organ damage development is associated with best survival and cure rate, while HSCT remains a risky therapeutic option for older patients, for those with organ damage, especially severe liver disease, and/or for those with limited or no donor availability. Prospective studies are needed to analyze risks of HSCT compared to those of life-long supportive therapy, including quality of life measures.

Keywords: HSCT, combined immunodeficiencies, decision to transplant, modalities and timing, CD40L 


\section{HETEROGENEITY OF COMBINED IMMUNODEFICIENCIES}

Combined immunodeficiencies (CIDs) are a clinically and genetically heterogeneous group of primary immunodeficiencies (PIDs) that affect T-lymphocyte immunity with abnormal development or function. Humoral immunity may be intrinsically abnormal or defective as a consequence of an abnormal T-B lymphocyte cooperation (1).

Clinically, CIDs are extremely variable in terms of manifestations, age of onset and severity. A broad susceptibility to opportunistic and non-opportunistic infections including viruses, bacteria, protozoan and parasites is a hallmark of these diseases. Defects of immune regulation are frequent and can lead to autoimmune and immune dysregulation manifestations that in some circumstances can be the predominant features. They occur in up to $40 \%$ of patients with CIDs, autoimmune cytopenia and inflammatory bowel diseases being the most frequent (2). Chronic non-malignant lymphoproliferation can occur. It can lead to skin or visceral granulomatous lesions driven in some circumstances by persistent chronic infections such as vaccine-derived rubella virus (3). Increased susceptibility to malignancies, particularly lymphoma is observed (4). This can be due to impaired immunosurveillance to viral or tumoral antigens; chronic inflammation and infection with oncogenic viruses such as Epstein Barr Virus (EBV) can also promote lymphoproliferation. In some PIDs, intrinsic defects of DNA repair may further increase these oncogenic risks. Some CIDs can be associated with syndromic features as microcephaly, dysmorphic features, intrinsic growth retardation (related to osseous dysplasia) (5).

Infectious, autoimmune, inflammatory and oncogenic complications and their specific treatments can lead to persistent damage to several organs including lung, liver, digestive tract, and/or kidney.

There is a continuum between severe combined immune deficiencies (SCID) and CIDs without consensual demarcation between these two groups of diseases (6). CIDs differ by a later age of onset, later age at diagnosis, generally beyond the age of 1 year, and by a higher number of circulating $\mathrm{T}$ lymphocytes. Immunological abnormalities are highly variable from profound quantitative or qualitative abnormalities to significant residual T-lymphocyte immunity. Humoral immunity is variably affected. At the other end of the spectrum, common variable immune deficiency (CVID) that occurs later in life is predominantly an antibody deficiency associated in some cases with an impaired T-cell immunity.

Molecular causes of CIDs are numerous and can affect either lymphopoiesis or T-lymphocyte function at several of the numerous developmental, activation or differentiation steps required for an efficient immune response (Table 1) (1). The international Union of Immunological Societies categorized and listed primary immunodeficiencies with known molecular causes (5) and more than 120 gene defects are responsible for CIDs.
Thanks to improved performance of next generation sequencing, there has been a rapid expansion in the identification of causative gene alterations among patients with CIDs in recent years. Genetic diagnostic is also shortened by these new approaches. However, a proportion of patients with CIDs remains without molecular diagnosis (37).

\section{HEMATOPOIETIC STEM CELL TRANSPLANTATION IN CIDS}

\section{Indication to Transplant}

Prognosis of CIDs is worse as compared to other PIDs such as humoral defects, innate, and granulocyte immune deficiencies (38). The curative treatment is often hematopoietic stem cell transplantation (HSCT) that has been increasingly successful in recent years. However, the broad spectrum of genetic defects underlying CIDs, the large range of T-cell defects and clinical heterogeneity in each disease make the decision about transplantation very challenging and prevent from universal recommendations regarding indication, timing and modalities of HSCT. Rather, it invites to disease and patient tailored treatment (39) that integrates and weights all these parameters including the characteristics of available donors to balance the final decision.

For patients with early severe clinical presentations mimicking SCID, the recommendation to drive the patient quickly to HSCT will be straightforward, including with alternative donors. However, no threshold of T-cell immunity required to prevent severe complications has been established. When molecular diagnosis is known, it may guide the decision for diseases with well-known natural history, helping to weight the balance between risks of disease evolution with potential development of future organ damage vs. risks of transplantation. However, many genetic causes of CIDs have been recently described, involving a small number of individuals with limited experiences, as summarized in Table 1. In these cases, natural history studies are needed. Several retrospective studies co-ordinated by the Inborn Error Working Party (IEWP) of the European Society for Bone and Marrow Transplantation (EBMT) are ongoing (e.g., in hypomorphic RAG1 and RAG2 deficiencies, CD27/CD70 deficiencies) and will help to define the best treatment strategies in these conditions. When the molecular diagnosis is unknown, the decision to proceed to transplant is mostly based on clinical judgement.

Retrospective studies performed in specific CIDs [WiskottAldrich syndrome (WAS), MHCII expression deficiency, CD40L deficiency, dedicator of cytokinesis 8 (DOCK8) deficiency] (4042) advocate for early transplantation before organ damage development or occurrence of severe, chronic infections [see reviews on Hematopoietic stem cell transplantation for WAS and DOCK8 deficiency (26) and for MHC class II expression deficiency]. Similar recommendations may apply more broadly to CIDs. The p-CID study, a prospective international multicentre observational study that is currently recruiting is designed to try to define clinical events and immunologic parameters predictive of outcome with the aim to help making the decision to transplant in these conditions (39). 
TABLE 1 | Non excaustive list of CID, their main clinical features and HSCT experiences.

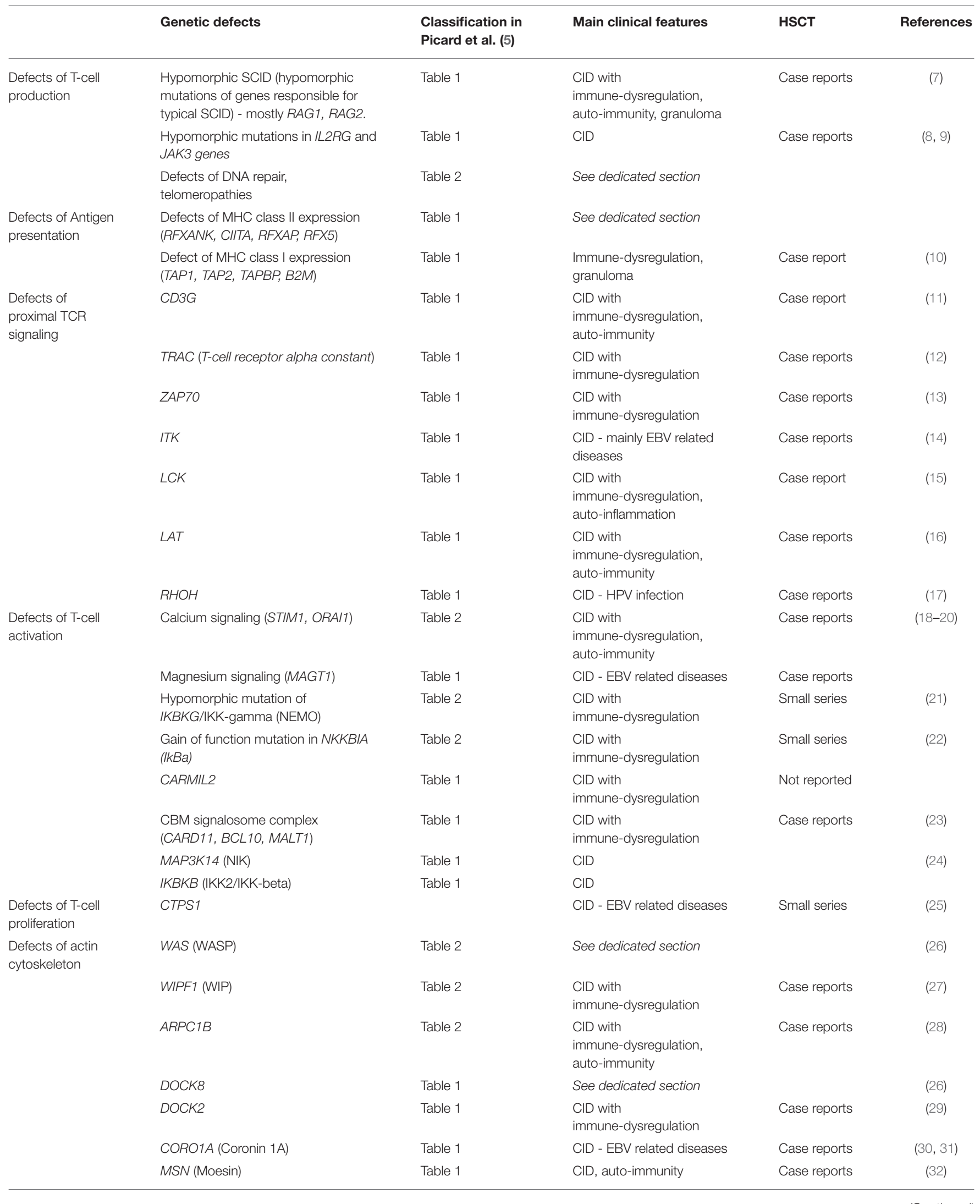


TABLE 1 | Continued

\begin{tabular}{|c|c|c|c|c|c|}
\hline & Genetic defects & $\begin{array}{l}\text { Classification in } \\
\text { Picard et al. (5) }\end{array}$ & Main clinical features & HSCT & References \\
\hline & RAC2 (dominant negative mutation) & Table 1 & $\begin{array}{l}\text { Lymphopenia, defective } \\
\text { neutrophil chemotaxis }\end{array}$ & Case reports & (33) \\
\hline & $\begin{array}{l}\text { RAC2 (homozygous loss of function } \\
\text { mutation) }\end{array}$ & Table 1 & CVID, autoimmunity & $\begin{array}{l}\text { No HSCT } \\
\text { reported }\end{array}$ & (34) \\
\hline & RAC2 (gain of function mutations) & Table 1 & CID & Case reports & \\
\hline & CD70 & Table 4 & $\begin{array}{l}\text { CID with immune } \\
\text { dysregulation and EBV } \\
\text { related disease }\end{array}$ & Case reports & \\
\hline & TNFRSF9 (4-1BB, CD137) & & $\begin{array}{l}\text { CID with immune } \\
\text { dysregulation and EBV } \\
\text { related disease }\end{array}$ & Case reports & \\
\hline & IL21-1L21R & Table 1 & & & \\
\hline & CD4O & Table 1 & $\mathrm{CID}$ & Small series & (35) \\
\hline & $C D 40 L G$ & Table 1 & CID & & \\
\hline \multirow{2}{*}{$\begin{array}{l}\text { Defects of } \\
\text { regulatory function } \\
\text { and other diseases } \\
\text { of immune } \\
\text { dysregulation }\end{array}$} & $\begin{array}{l}\text { IPEX (FOXP3), IL2RA (CD25), IL10, } \\
\text { IL10R1, IL10R2, CTLA4, LRBA }\end{array}$ & Table 4 & See dedicated section & & \\
\hline & PIK3CD (GOF), PIK3R1 (LOF) & Table 3 & $\begin{array}{l}\text { CID with } \\
\text { immune-dysregulation, } \\
\text { auto-immunity }\end{array}$ & Small series & (36) \\
\hline
\end{tabular}

ID, immunodeficiencies, CID, combined immunodeficiencies, SCID, severe combined immunodeficiencies. Table 1: ID affecting cellular and humoral immunity; Table 2: CID with associated or syndromic features; Table 3: Predominantly antibody deficiencies; Table 4: Diseases of immune dysregulation (susceptibility to EBV and lymphoproliferative conditions).

The donor availability needs also to be considered for the transplant decision. Whatever the diagnosis, HSCT from a healthy matched sibling donor (MSD) remains the gold standard that offers the best results and allows to consider HSCT early in the course of the disease, even pre-emptively if poor outcome is predictable (38) [see reviews on Hematopoietic stem cell transplantation for WAS and DOCK8 deficiency (26) and for MHC class II expression deficiency]. Outcomes obtained with matched unrelated donors (MUD) have increasingly improved in the last decade and are approaching similar survival rates as with MSD [albeit with higher rate of HSCT-related complications (41)] [see review on Hematopoietic stem cell transplantation for WAS and DOCK8 deficiency (26)], allowing extended indications. In the absence of a matched-donor, decision to transplant needs to be balanced. Transplantation from an alternative donor is more challenging even though most recent results show increasingly successful survival, allowing to consider transplant early in the disease course (43-46). At the end, the final decision about transplant will depend on a conjunction of factors such as immunological parameters, the severity of past and current clinical manifestations, i.e., severity of infections, autoimmunity, need of immunosuppressive treatment to control the manifestations related to immune dysregulation and donor compatibility. Family history and their experience with the disease will also weight in the final decision.

\section{Pre-HSCT Evaluation}

Cautious evaluation by a multi-disciplinary team is important before transplantation. Previous recurrent or chronic infections may have led to severe and irreversible visceral damage, notably lung and liver. Renal impairment can also occur as a consequence of chronic or recurrent anti-infectious treatment or prolonged immunosuppression. Aggressive pre-emptive treatment and control of all treatable pre-existing infections needs to be proposed prior HSCT. Special attention to detect emergence of antimicrobial drug resistance need to be given, especially in heavily pre-treated patients. In case of EBVrelated lymphoproliferation prior to HSCT, the degree of remission required before transplant is a question of debate (47). Optimization of nutritional status is also important. Remission of pre-existing autoimmunity and/or inflammatory conditions should as much as possible be obtained before transplantation, while avoiding prolonged heavy immunosuppression both before and after HSCT that may increase infectious susceptibility. 


\section{Conditioning Regimen and GVHD Prophylaxis}

The residual T-cell immunity and the intact hematopoiesis of these patients increases the risk of allograft rejection, particularly in case of HLA disparity between donor and recipient. Some degree of myeloablation is usually required. Development of reduced toxicity conditioning regimens (CR) has contributed to reduce transplant-related mortality (TRM) in the last decade $(48,49)$. Currently, the most frequent associations proposed from the more myeloablative to the more reduced intensity are busulfan/fludarabine, treosulfan/fludarabine, and fludarabine/melphalan. In the absence of organ damage, myeloablative conditioning (MAC) is preferred, while reduced intensity conditioning (RIC) will be considered in case of pre-HSCT co-morbidities. Addition of tiothepa to treosulfan/fludarabine can be discussed in case of mismatched transplant, especially if an ex vivo manipulation of the graft is proposed. Addition of serotherapy (anti-thymocytes globulins or alemtuzumab) is frequently recommended to prevent rejection and GVHD, but its omission can be discussed in HSCT from a MSD. In case of pre-HSCT autoimmunity, treatment with anti-CD20 monoclonal antibodies can be proposed.

Full donor chimerism in all lineages is not always mandatory to correct the underlying disease with exceptions such as WAS, where mixed chimerism has been related to inferior long-term outcome (autoimmunity and thrombocytopenia) $(45,50)$.

The risk of occurrence of graft-vs.-host-disease (GVHD) is dependent on the degree of compatibility between donor and recipient, but also on the clinical conditions of the recipient. Preexisting viral infections or inflammation related to autoimmunity or immune dysregulation can predispose to onset of early and severe acute GVHD and therefore, effective GVHD prophylaxis is of primary importance. If GVHD occurs, it needs to be aggressively and rapidly treated.

\section{Donor Choice}

HSCT from a geno-identical healthy sibling remains the best option, but available in fewer than $25 \%$ of cases. A suitable MUD will be available in $\sim 70 \%$ of the remaining patients, or even less for patients belonging to ethnic groups insufficiently represented in donor registries (51). Options will be HSCT from an alternative donor, i.e., unrelated mismatched cord-blood (MMCB), mismatched unrelated donor (MMUD), or HLAhaploidentical mismatched family donor (MMFD). In MMUD and MMFD, different types of graft manipulations have been developed to reduce risks of GVHD and graft rejection (52). Historically, CD34+ cell selection was the most commonly used technique, but non-engraftment and slow immune reconstitution limited its applications especially in CIDs. New strategies with selective depletions as CD3/CD19 or TCRalpha/beta and CD19 depletions are increasingly used, limiting the risk of GVHD and allowing good engraftment rate, as long as a myeloablative conditioning (MAC) is administered $(53,54)$. However, poor early immune reconstitution might still be problematic notably in patients with active infection at the time of HSCT. Haplo-HSCT strategies without ex vivo graft manipulation, but using posttransplant cyclophosphamide (PTCY) as GVHD prophylaxis, have been increasingly used to treat adult patients with malignant diseases. Data on PTCY in children with PIDs and CIDs are still limited but encouraging $(43,44)$. All these alternative approaches need to be prospectively compared in the context of CIDs.

In conclusion, early molecular diagnosis to facilitate early decision of transplantation before development of co-morbidities, tailoring conditioning regimen to reduce toxicity, improving GVHD prophylaxis and kinetics of immune reconstitution while improving supportive care, are future perspectives that should contribute to improvement of HSCT results in CIDs.

\section{THE EXAMPLE OF CD40L DEFICIENCY: HSCT VS. LONG-TERM SUPPORTIVE TREATMENT}

CD40 ligand (CD40L) deficiency $(55,56)$ is a X-linked disease related to hemizygous mutations in CD40LG gene, encoding CD40L, a glycoprotein (5, 57-61) mainly involved in co-stimulatory T-lymphocyte function. Impaired CD40L expression alters B-cell isotype switching and antibody production, dendritic cell signaling, and myeloid cell function and development $(62,63)$. Generally, disease onset occurs during early childhood, with frequent respiratory tract infections, diarrhea and neutropenia. As a consequence of chronic cryptosporidial infection, severe biliary tract disease may develop and evolve to sclerosing cholangitis.

CD40L deficiency is associated with high morbidity and mortality. Historically, long-term survival has been poor with supportive therapy only, with $20-50 \%$ of patients reaching their thirties (64-66) and only sporadic observations of longterm survivors $(67,68)$. A median survival of 25 years from diagnosis has been recently shown in 109 patients treated with conservative therapy only (67). This approach currently includes immunoglobulin replacement (IgR), antimicrobial prophylaxis, close monitoring for complications, and careful precautions to avoid Cryptosporidium species exposure. Liver disease is the most significant predictor of mortality $(67,69)$ and, together with severe infections, represents the major cause of death (64).

At present, HSCT represents the only curative treatment for this disease. Historically, its outcome has not been optimal (65). In a first European retrospective survey (70), overall survival (OS) after HSCT was $68 \%$ and transplant was curative in only $58 \%$ of patients, most of whom without liver disease. More recently, the multi-center retrospective observational study of de la Morena et al. showed similar OS between patients with CD40L deficiency treated with or without HSCT, but among survivors, transplanted patients showed higher median age performance status scores and greater well-being, as compared to nontransplanted patients (67). In addition, a survival improvement for transplanted patients was progressively observed since 1987, 
suggesting better transplant practices in more recent years (67). This positive trend was confirmed by a recent Japanese study (71), reporting improved outcome in 29 patients undergoing HSCT, and also by a subsequent international retrospective survey (42), in which HSCT outcome was analyzed in 130 patients with CD40L deficiency transplanted between 1993 and 2015. In this study, OS, event-free (EFS) and diseasefree survival (DFS) 5 years post-HSCT were 78.2, 58.1, and $72.3 \%$, respectively. A general HSCT outcome improvement was confirmed after 2000, mainly thanks to amelioration of transplant-related procedures, earlier age at transplantation, and lower organ damage burden, especially liver disease. Indeed, after 2000 , best results were obtained in children transplanted before 5 years, while organ damage before HSCT was confirmed to negatively influence outcome (42). Superior OS was achieved with matched donors, both MSD and MUD. Myeloablation resulted in better OS and DFS, as compared to RIC. Moreover, MAC was associated with higher EFS. Among survivors who could stop IgR, T-lymphocyte chimerism was mainly donor in most. However, decreasing lineage-specific chimerism was observed in some transplants, underlying the problem of residual host immunity. In line with this, myeloablation seemed to be required to attain complete engraftment. Indeed, RIC and nonmyeloablative conditioning resulted associated with poor or absent engraftment.

Interestingly, de la Morena et al. (67) evidenced geographic differences in HSCT practices: indication for HSCT was variable, with higher transplant rates in European centers as compared to American ones. This is a reflection of the still unsolved debate about the best management of these patients. Guidelines were proposed by the European Society for Blood and Marrow Transplantation/European Society for Immunodeficiencies Inborn Errors Working Party in 2011 (72). These recommendations favored HSCT at diagnosis in case

\section{REFERENCES}

1. Fischer A, Notarangelo LD, Neven B, Cavazzana M, Puck JM. Severe combined immunodeficiencies and related disorders. Nat Rev Dis Prim. (2015) 1:15061. doi: 10.1038/nrdp.2015.61

2. Fischer A, Provot J, Jais JP, Alcais A, Mahlaoui N. Autoimmune and inflammatory manifestations occur frequently in patients with primary immunodeficiencies. J Allergy Clin Immunol. (2017) 140:1388-1393.e8. doi: $10.1016 /$ j.jaci.2016.12.978

3. Buchbinder D, Hauck F, Albert MH, Rack A, Bakhtiar S, Shcherbina A, et al. Rubella virus-associated cutaneous granulomatous disease: a unique complication in immune-deficient patients, not limited to DNA repair disorders. J Clin Immunol. (2019) 39:81-9. doi: 10.1007/s10875-018-0581-0

4. Bomken S, van der Werff Ten Bosch J, Attarbaschi A, Bacon CM, Borkhardt A, Boztug K, et al. Current understanding and future research priorities in malignancy associated with inborn errors of immunity and DNA repair disorders: the perspective of an interdisciplinary working group. Front Immunol. (2018) 9:2912. doi: 10.3389/fimmu.2018.02912

5. Picard C, Bobby Gaspar H, Al-Herz W, Bousfiha A, Casanova J-L, Chatila $\mathrm{T}$, et al. International union of immunological societies: 2017 primary immunodeficiency diseases committee report on inborn errors of immunity. $J$ Clin Immunol. (2018) 38:96-128. doi: 10.1007/s10875-017-0464-9

6. ESIDRegistry_ClinicalCriteria. Available online at: https://esid.org/WorkingParties/Registry-Working-Party/Diagnosis-criteria of MSD availability, HSCT at early complication development in case of MUD or MMUD, and later, salvage HSCT in case of progressive organ damage for those with MMFD available only. However, recently published data prompt an update of these guidelines, suggesting that HSCT can cure CD40L deficiency, but its outcome is better if it is performed upfront, before the development of organ damage, and using MAC, which associated with higher survival and cure rate. In addition, it was recently shown (73) that an effective early HSCT can also improve or even reverse mild to moderate chronic cholangiopathy, presumably thanks to the clearance of chronic infections after immune reconstitution. Nevertheless, in spite of recent outcome amelioration, HSCT still remains a risky therapeutic option for older patients, for those with organ damage, especially severe liver disease, and/or for those with limited donor availability. For these patients, gene editing may represent an attractive potential alternative treatment, since infusion of gene-corrected T-lymphocytes or HSC may be curative $(74,75)$ [see review on "Autologous stem cellbased gene therapy for inherited disorders: state-of-the-art and future prospects" (76)]. Finally, prospective studies are needed to perform comparative analyses about the risks of HSCT and those of life-long supportive therapy, including quality of life measures. Detailed longitudinal clinical data are lacking, especially regarding infection-related burden in terms of frequency of hospital admissions or missed days of school/work. These are fundamental to standardize patients' management aimed not only at improving survival, but also at optimizing quality of life.

\section{AUTHOR CONTRIBUTIONS}

All authors listed have made a substantial, direct and intellectual contribution to the work, and approved it for publication.

7. John T, Walter J, Schuetz C, Chen K, Abraham R, Bonfim C, et al. Unrelated hematopoietic cell transplantation in a patient with combined immunodeficiency with granulomatous disease and autoimmunity secondary to RAG deficiency. J Clin lmmunol. (2016) 36:725-32. doi: 10.1007/s10875-016-0326-x

8. Stepensky P, Keller B, Shamriz O, von Spee-Mayer C, Friedmann D, Shadur $B$, et al. T+ NK+ IL-2 receptor $\gamma$ chain mutation: a challenging diagnosis of atypical severe combined immunodeficiency. J Clin Immunol. (2018) 38:52736. doi: 10.1007/s10875-018-0514-y

9. Farnault L, Chambost H, Michel G, Thuret I, de Saint Basile G, Fischer A, et al. Persistence of natural killer cells with expansion of a hypofunctional CD56-CD16+KIR+NKG2C+ subset in a patient with atypical Janus kinase 3deficient severe combined immunodeficiency. J Allergy Clin Immunol. (2013) 131:1230-3. doi: 10.1016/j.jaci.2012.08.047

10. Gao Y, Arkwright PD, Carter R, Cazaly A, Harrison RJ, Mant A, et al. Bone marrow transplantation for MHC class I deficiency corrects T-cell immunity but dissociates natural killer cell repertoire formation from function. J Allergy Clin Immunol. (2016) 138:1733-6.e2. doi: 10.1016/j.jaci.2016.06.029

11. Ozgür T, Asal G, Cetinkaya D, Orhan D, Kiliç S, Usta Y, et al. Hematopoietic stem cell transplantation in a CD3 gamma-deficient infant with inflammatory bowel disease. Pediatr Transplant. (2008) 12:910-3. doi: 10.1111/j.1399-3046.2008.00957.x

12. Morgan N, Goddard S, Cardno T, McDonald D, Rahman F, Barge D, et al. Mutation in the TCR $\alpha$ subunit constant gene (TRAC) leads to a human 
immunodeficiency disorder characterized by a lack of TCR $\alpha \beta+\mathrm{T}$ cells. J Clin Invest. (2011) 121:695-702. doi: 10.1172/JCI41931

13. Cuvelier G, Rubin T, Wall D, Schroeder M. Long-term outcomes of hematopoietic stem cell transplantation for ZAP70 deficiency. J Clin Immunol. (2016) 36:713-24. doi: 10.1007/s10875-016-0316-z

14. Ghosh S, Drexler I, Bhatia S, Gennery AR, Borkhardt A. Interleukin-2inducible T-cell kinase deficiency-new patients, new insight? Front Immunol. (2018) 9:979. doi: 10.3389/fimmu.2018.00979

15. Hauck F, Randriamampita C, Martin E, Gerart S, Lambert N, Lim A, et al. Primary T-cell immunodeficiency with immunodysregulation caused by autosomal recessive LCK deficiency. J Allergy Clin Immunol. (2012) 130:114452.e11. doi: 10.1016/j.jaci.2012.07.029

16. Keller B, Zaidman I, Yousefi O, Hershkovitz D, Stein J, Unger S, et al. Early onset combined immunodeficiency and autoimmunity in patients with loss-of-function mutation in LAT. J Exp Med. (2016) 213:1185-99. doi: $10.1084 /$ jem.20151110

17. Crequer A, Troeger A, Patin E, Ma C, Picard C, Pedergnana V, et al. Human RHOH deficiency causes T cell defects and susceptibility to EV-HPV infections. J Clin Invest. (2012) 122:3239-47. doi: 10.1172/JCI62949

18. Picard C, McCarl C, Papolos A, Khalil S, Lüthy K, Hivroz $\mathrm{C}$, et al. STIM1 mutation associated with a syndrome of immunodeficiency and autoimmunity. N Engl J Med. (2009) 360:1971-80. doi: 10.1056/NEJMoa0900082

19. Feske S, Gwack Y, Prakriya M, Srikanth S, Puppel S, Tanasa B, et al. A mutation in Orail causes immune deficiency by abrogating CRAC channel function. Nature. (2006) 441:179-85. doi: 10.1038/nature04702

20. Lian J, Cuk M, Kahlfuss S, Kozhaya L, Vaeth M, Rieux-Laucat F, et al. ORAI1 mutations abolishing store-operated $\mathrm{Ca} 2+$ entry cause anhidrotic ectodermal dysplasia with immunodeficiency. J Allergy Clin Immunol. (2018) 142:1297-310.e11. doi: 10.1016/j.jaci.2017.10.031

21. Miot $C$, Imai $K$, Imai $C$, Mancini $A$, Kucuk $Z$, Kawai $T$, et al. Hematopoietic stem cell transplantation in 29 patients hemizygous for hypomorphic IKBKG/NEMO mutations. Blood. (2017) 130:1456-67. doi: 10.1182/blood-2017-03-771600

22. Boisson B, Puel A, Picard C, Casanova J. Human IкB $\alpha$ gain of function: a severe and syndromic immunodeficiency. J Clin Immunol. (2017) 37:397-412. doi: $10.1007 / \mathrm{s} 10875-017-0400-\mathrm{z}$

23. Turvey S, Durandy A, Fischer A, Fung S, Geha R, Gewies A, et al. The CARD11-BCL10-MALT1 (CBM) signalosome complex: stepping into the limelight of human primary immunodeficiency. J Allergy Clin Immunol. (2014) 134:276-84. doi: 10.1016/j.jaci.2014.06.015

24. Willmann K, Klaver S, Dogu F, Santos-Valente E, Garncarz W, Bilic I, et al. Biallelic loss-of-function mutation in NIK causes a primary immunodeficiency with multifaceted aberrant lymphoid immunity. Nat Commun. (2014) 19:5360. doi: 10.1038/ncomms6360

25. Nademi Z, Wynn R, Slatter M, Hughes S, Bonney D, Qasim W, et al. Hematopoietic stem cell transplantation for cytidine triphosphate synthase 1 (CTPS1) deficiency. Bone Marrow Transplant. (2019) 54:130-3. doi: 10.1038/s41409-018-0246-x

26. Albert MH, Freeman AF. Wiskott-Aldrich Syndrome (WAS) and dedicator of Cytokinesis 8 (DOCK8) deficiency. Front Pediatr. (2019) 7:451. doi: $10.3389 /$ fped.2019.00451

27. Al-Mousa H, Hawwari A, Al-Ghonaium A, Al-Saud B, Al-Dhekri H, Al-Muhsen S, et al. Hematopoietic stem cell transplantation corrects WIP deficiency. J Allergy Clin Immunol. (2017) 139:1039-40.e4. doi: 10.1016/j.jaci.2016.08.036

28. Volpi S, Cicalese M, Tuijnenburg P, Tool A, Cuadrado E, Abu-Halaweh M, et al. A combined immunodeficiency with severe infections, inflammation, and allergy caused by ARPC1B deficiency. J Allergy Clin Immunol. (2019) 143:2296-9. doi: 10.1016/j.jaci.2019.02.003

29. Dobbs K, Domínguez Conde C, Zhang S, Parolini S, Audry M, Chou J, et al. Inherited DOCK2 deficiency in patients with early-onset invasive infections. N Engl J Med. (2015) 372:2409-22. doi: 10.1056/NEJMoa1413462

30. Moshous D, Martin E, Carpentier W, Lim A, Callebaut I, Canioni D, et al. Whole-exome sequencing identifies Coronin-1A deficiency in 3 siblings with immunodeficiency and EBV-associated B-cell lymphoproliferation. J Allergy Clin Immunol. (2013) 131:1594-603. doi: 10.1016/j.jaci.2013.01.042
31. Shiow L, Roadcap D, Paris K, Watson S, Grigorova I, Lebet T, et al. The actin regulator coronin $1 \mathrm{~A}$ is mutant in a thymic egress-deficient mouse strain and in a patient with severe combined immunodeficiency. Nat Immunol. (2008) 9:1307-15. doi: 10.1038/ni.1662

32. Henrickson SE, Andre-Schmutz I, Lagresle-Peyrou C, Deardorff M, Jyonouchi H, Neven B, et al. Hematopoietic stem cell transplant for the treatment of X-MAID. Front Pediatr. (2019) 7:170. doi: 10.3389/fped.2019. 00170

33. Accetta D, Syverson G, Bonacci B, Reddy S, Bengtson C, Surfus J, et al. Human phagocyte defect caused by a Rac2 mutation detected by means of neonatal screening for T-cell lymphopenia. J Allergy Clin Immunol. (2011) 127:535-8. doi: 10.1016/j.jaci.2010.10.013

34. Alkhairy OK, Rezaei N, Graham RR, Abolhassani H, Borte S, Hultenby K, et al. RAC2 loss-of-function mutation in 2 siblings with characteristics of common variable immunodeficiency. J Allergy Clin Immunol. (2015) 135:1380-4.e5. doi: 10.1016/j.jaci.2014.10.039

35. Al-Saud B, Al-Jomaie M, Al-Ghonaium A, Al-Ahmari A, Al-Mousa H, AlMuhsen S, et al. Haematopoietic stem cell transplant for hyper-IgM syndrome due to CD40 defects: a single-centre experience. Bone Marrow Transplant. (2019) 54:63-7. doi: 10.1038/s41409-018-0219-0

36. Nademi Z, Slatter MA, Dvorak CC, Neven B, Fischer A, Suarez F, et al. Hematopoietic stem cell transplant in patients with activated PI3K delta syndrome. J Allergy Clin Immunol. (2017) 139:1046-9. doi: $10.1016 /$ j.jaci.2016.09.040

37. Mahlaoui N, Picard C, Bach PB, Costes LB, Courteille VB, Ranohavimparany A, et al. Genetic diagnosis of primary immunodeficiencies: a survey of the French national registry. J Allergy Clin Immunol. (2019) 143:1646-1649.e10. doi: 10.1016/j.jaci.2018.12.994

38. Gennery AR, Slatter MA, Grandin L, Taupin P, Cant AJ, Veys P, et al. Transplantation of hematopoietic stem cells and long-term survival for primary immunodeficiencies in Europe: entering a new century, do we do better? J Allergy Clin Immunol. (2010) 126:602-10.e1.11. doi: $10.1016 /$ j.jaci.2010.06.015

39. Speckmann C, Doerken S, Aiuti A, Albert MH, Al-Herz W, Allende LM, et al. A prospective study on the natural history of patients with profound combined immunodeficiency: an interim analysis. J Allergy Clin Immunol. (2017) 139:1302-1310.e4. doi: 10.1016/j.jaci.2016.07.040

40. Klein C, Cavazzana-Calvo M, Le Deist F, Jabado N, Benkerrou M, Blanche $S$, et al. Bone marrow transplantation in major histocompatibility complex class II deficiency: a single-center study of 19 patients. Blood. (1995) 85:580-7. doi: 10.1182/blood.V85.2.580.580

41. Aydin SE, Freeman AF, Al-Herz W, Al-Mousa HA, Arnaout RK, Aydin RC, et al. Hematopoietic stem cell transplantation as treatment for patients with DOCK8 deficiency. J Allergy Clin Immunol Pract. (2019) 7:848-55. doi: 10.1016/j.jaip.2018.10.035

42. Ferrua F, Galimberti S, Courteille V, Slatter MA, Booth C, Moshous D, et al. Hematopoietic stem cell transplantation for $\mathrm{CD} 40$ ligand deficiency: results from an EBMT/ESID-IEWP-SCETIDE-PIDTC Study. J Allergy Clin Immunol. (2019) 143:2238-53. doi: 10.1016/j.jaci.2018.12.1010

43. Neven B, Diana JS, Castelle M, Magnani A, Rosain J, Touzot F, et al. Haploidentical hematopoietic stem cell transplantation with posttransplant cyclophosphamide for primary immunodeficiencies and inherited disorders in children. biol blood marrow transplant. (2019) 25:1363-73. doi: 10.1016/j.bbmt.2019.03.009

44. Kurzay M, Hauck F, Schmid I, Wiebking V, Eichinger A, Jung E, et al. Tcell replete haploidentical bone marrow transplantation and post-transplant cyclophosphamide for patients with inborn errors. Haematologica. (2019) 104:e478-82. doi: 10.3324/haematol.2018.215285

45. Elfeky R, Furtado-Silva J, Chiesa R, Rao K, Amrolia P, Lucchini G, et al. One hundred percent survival after transplantation of 34 patients with WiskottAldrich syndrome over 20 years. J Allergy Clin Immunol. (2018) 142:16546.e7. doi: 10.1016/j.jaci.2018.06.042

46. Balashov D, Laberko A, Shcherbina A, Trakhtman P, Abramov D, Gutovskaya $\mathrm{E}$, et al. A conditioning regimen with plerixafor is safe and improves the outcome of TCR $\alpha \beta+$ and CD19+ Cell-depleted stem cell transplantation in patients with wiskott-aldrich syndrome. Biol Blood Marrow Transpl. (2018) 24:1432-40. doi: 10.1016/j.bbmt.2018.03.006 
47. Cohen JM, Sebire NJ, Harvey J, Gaspar HB, Cathy C, Jones A, et al. Successful treatment of lymphoproliferative disease complicating primary immunodeficiency/immunodysregulatory disorders with reducedintensity allogeneic stem-cell transplantation. Blood. (2007) 110:2209-14. doi: 10.1182/blood-2006-12-062174

48. Worth AJJ, Booth C, Veys P. Stem cell transplantation for primary immune deficiency. Curr Opin Hematol. (2013) 20:501-8. doi: 10.1097/MOH.0b013e328365a13b

49. Slatter MA, Rao K, Abd Hamid IJ, Nademi Z, Chiesa R, Elfeky R, et al. Treosulfan and fludarabine conditioning for hematopoietic stem cell transplantation in children with primary immunodeficiency: UK experience. Biol Blood Marrow Transplant. (2018) 24:529-36. doi: 10.1016/j.bbmt.2017.11.009

50. Moratto D, Giliani S, Bonfim C, Mazzolari E, Fischer A, Ochs HD, et al. Longterm outcome and lineage-specific chimerism in 194 patients with WiskottAldrich syndrome treated by hematopoietic cell transplantation in the period 1980-2009: an international collaborative study. Blood. (2011) 118:1675-84. doi: 10.1182/blood-2010-11-319376

51. Gragert L, Eapen M, Williams E, Freeman J, Spellman S, Baitty R, et al. HLA Match likelihoods for hematopoietic stem-cell grafts in the U.S. registry. $N$ Engl J Med. (2014) 371:339-87. doi: 10.1056/NEJMsa1311707

52. Locatelli F, Vinti L, Palumbo G, Rossi F, Bertaina A, Mastronuzzi A, et al. Strategies to optimize the outcome of children given T-cell depleted HLA-haploidentical hematopoietic stem cell transplantation. Best Pract Res Clin Haematol. (2011) 24:339-49. doi: 10.1016/j.beha.2011. 04.004

53. Shah RM, Elfeky R, Nademi Z, Qasim W, Amrolia P, Chiesa R, et al. Tcell receptor $\alpha \beta+$ and CD19+ cell-depleted haploidentical and mismatched hematopoietic stem cell transplantation in primary immune deficiency. J Allergy Clin Immunol. (2018) 141:1417-26.e1. doi: 10.1016/j.jaci.2017. 07.008

54. Bertaina A, Merli P, Rutella S, Pagliara D, Bernardo ME, Masetti R, et al. HLA-haploidentical stem cell transplantation after removal of $\alpha \beta+\mathrm{T}$ and B cells in children with nonmalignant disorders. Blood. (2014) 124:822-6. doi: 10.1182/blood-2014-03-563817

55. DiSanto JP, Bonnefoy JY, Gauchat JF, Fischer A, de Saint Basile G. CD40 ligand mutations in X-linked immunodeficiency with hyper-IgM. Nature. (1993) 361:541-3. doi: 10.1038/361541a0

56. Notarangelo LD, Peitsch MC, Abrahamsen TG, Bachelot C, Bordigoni P, Cant AJ, et al. CD40lbase: a database of CD40L gene mutations causing X-linked hyper-IgM syndrome. Immunol Today. (1996) 17:511-6. doi: 10.1016/S0167-5699(96)80904-2

57. Korthäuer U, Graf D, Mages HW, Brière F, Padayachee M, Malcolm S, et al. Defective expression of T-cell CD40 ligand causes X-linked immunodeficiency with hyper-IgM. Nature. (1993) 361:539-41. doi: 10.1038/361539a0

58. Kroczek RA, Graf D, Brugnoni D, Giliani S, Korthüer U, Ugazio A, et al. Defective expression of CD40 ligand on T cells causes "X-linked immunodeficiency with hyper-IgM (HIGM1).” Immunol Rev. (1994) 138:3959. doi: 10.1111/j.1600-065X.1994.tb00846.x

59. Allen R, Armitage R, Conley M, Rosenblatt H, Jenkins N, Copeland N, et al. CD40 ligand gene defects responsible for X-linked hyper-IgM syndrome. Science. (1993) 259:990-3. doi: 10.1126/science.7679801

60. Aruffo A, Farrington M, Hollenbaugh D, Li X, Milatovich A, Nonoyama $\mathrm{S}$, et al. The CD40 ligand, gp39, is defective in activated $\mathrm{T}$ cells from patients with X-linked hyper-IgM syndrome. Cell. (1993) 72:291-300. doi: 10.1016/0092-8674(93)90668-G

61. Fuleihan R, Ramesh N, Loh R, Jabara H, Rosen R, Chatila T, et al. Defective expression of the CD40 ligand in X chromosome-linked immunoglobulin deficiency with normal or elevated IgM. Proc Natl Acad Sci USA. (1993) 90:2170-3. doi: 10.1073/pnas.90.6.2170

62. Cabral-Marques O, Ramos RN, Schimke LF, Khan TA, Amaral EP, Barbosa Bomfim CC, et al. Human CD40 ligand deficiency dysregulates the macrophage transcriptome causing functional defects that are improved by exogenous IFN-צ. J Allergy Clin Immunol. (2017) 139:900-12. doi: $10.1016 /$ j.jaci.2016.07.018
63. Cabral-Marques O, França TT, Al-Sbiei A, Schimke LF, Khan TA, Feriotti C, et al. CD40 ligand deficiency causes functional defects of peripheral neutrophils that are improved by exogenous IFN- $\curlyvee$. J Allergy Clin Immunol. (2018) 142:1571-88.e9. doi: 10.1016/j.jaci.2018.02.026

64. Levy J, Espanol-Boren T, Thomas C, Fischer A, Tovo P, Bordigoni P, et al. Clinical spectrum of X-linked hyper-IgM syndrome. J Pediatr. (1997) 131:47-54. doi: 10.1016/S0022-3476(97)70123-9

65. Rezaei N, Notarangelo LD. Hematopoietic stem cell transplantation for hyperIgM syndromes. Pediatr Transplant. (2013) 17:1-2. doi: 10.1111/petr.12012

66. Winkelstein JA, Marino MC, Ochs H, Fuleihan R, Scholl PR, Geha R, et al. The X-linked hyper-IgM syndrome: clinical and immunologic features of 79 patients. Medicine. (2003) 82:373-84. doi: 10.1097/01.md.0000100046.06009.b0

67. de la Morena MT, Leonard D, Torgerson TR, Cabral-Marques O, Slatter M, Aghamohammadi A, et al. Long-term outcomes of 176 patients with X-linked hyper-IgM syndrome treated with or without hematopoietic cell transplantation. J Allergy Clin Immunol. (2017) 139:128292. doi: 10.1016/j.jaci.2016.07.039

68. Kutukculer N, Karaca N, Aksu G, Aykut A, Pariltay E, Cogulu O. An X-linked hyper-IgM patient followed successfully for 23 years without hematopoietic stem cell transplantation. Case Reports Immunol. (2018) 2018:6897935. doi: 10.1155/2018/6897935

69. Azzu V, Kennard L, Morillo-Gutierrez B, Slatter M, Edgar JDM, Kumararatne DS, et al. Liver disease predicts mortality in patients with X-linked immunodeficiency with hyper-IgM but can be prevented by early hematopoietic stem cell transplantation. J Allergy Clin Immunol. (2018) 141:405-8.e7. doi: 10.1016/j.jaci.2017.06.036

70. Gennery AR, Khawaja K, Veys P, Bredius RGM, Notarangelo LD, Mazzolari E, et al. Treatment of CD40 ligand deficiency by hematopoietic stem cell transplantation: a survey of the European experience, 1993-2002. Blood. (2004) 103:1152-7. doi: 10.1182/blood-2003-06-2014

71. Mitsui-Sekinaka K, Imai K, Sato H, Tomizawa D, Kajiwara M, Nagasawa $\mathrm{M}$, et al. Clinical features and hematopoietic stem cell transplantations for CD40 ligand deficiency in Japan. J Allergy Clin Immunol. (2015) 136:1018-24. doi: 10.1016/j.jaci.2015.02.020

72. EBMT/ESID. Guidelines for Haematopoietic Stem Cell Transplantation for Primary Immunodeficiency (2017). Available online at: https://esid.org/layout/ set/print/Working-Parties/Inborn-Errors-Working-Party-IEWP/Resources/ UPDATED!-EBMT-ESID-GUIDELINES-FOR-HAEMATOPOIETICSTEM-CELL-TRANSPLANTATION-FOR-PI

73. HadŽić N, Nademi Z, Deheragoda M, Zen Y, Elfeky R, Worth A, et al. Chronic cholangiopathy associated with primary immune deficiencies can be resolved by effective hematopoietic stem cell transplantation. J Pediatr. (2019) 209:97-106.e2. doi: 10.1016/j.jpeds.2019.01.015

74. Hubbard N, Hagin D, Sommer K, Song Y, Khan I, Clough C, et al. Targeted gene editing restores regulated CD40L function in X-linked hyper-IgM syndrome. Blood. (2016) 127:2513-23. doi: 10.1182/blood-2015-11-683235

75. Kuo CY, Long JD, Campo-Fernandez B, de Oliveira S, Cooper AR, Romero Z, et al. Site-specific gene editing of human hematopoietic stem cells for X-linked hyper-IgM syndrome. Cell Rep. (2018) 23:2606-16. doi: 10.1016/j.celrep.2018.04.103

76. Staal FJT, Aiuti A, Cavazzana M. Autologous stem-cell-based gene therapy for inherited disorders: state of the art and perspectives. Front Pediatr. (2019) 7:443. doi: $10.3389 /$ fped.2019.00443

Conflict of Interest: The authors declare that the research was conducted in the absence of any commercial or financial relationships that could be construed as a potential conflict of interest.

Copyright (c) 2020 Neven and Ferrua. This is an open-access article distributed under the terms of the Creative Commons Attribution License (CC BY). The use, distribution or reproduction in other forums is permitted, provided the original author(s) and the copyright owner(s) are credited and that the original publication in this journal is cited, in accordance with accepted academic practice. No use, distribution or reproduction is permitted which does not comply with these terms. 